\title{
Bioremediation of soil contaminated by spent diesel oil using Pleurotus pulmonarius Fries (Quelet) and its effects on the growth of Corchorus olitorius (L)
}

\author{
${ }^{*}$ Adenipekun C. $0^{1}$, Ayanleye. 0.0², Oyetunji 0.J3 \\ ${ }^{123}$, Department of Botany, University of Ibadan, Ibadan, Nigeria. \\ *Corresponding author email: oyinpek@yahoo.com
}

Original submitted in on 28 $8^{\text {th }}$ February 2013 Published online at www.m.elewa.org on $2^{\text {nd }}$ September 2013. https://dx.doi.org/10.4314/jab.v68i0.95063

\begin{abstract}
Objectives: To investigate the potential of Pleurotus pulmonarius in the bioremediation of soil contaminated with spent diesel oil at 5,10 and $15 \%(\mathrm{v} / \mathrm{w}$ ) levels) of contamination over a period of one and two months of incubation.

Methodology and results: A pure culture of $P$. pulmonarius was obtained from the Plant physiology unit of the Department of Botany; University of Ibadan Two sets of control were used. In the first set of control treatments, no contaminant (spent diesel oil) was added to the soils while in the second set, different levels of the oil were added to all soils but no inoculation with the fungus). Inoculation was done by adding $10 \mathrm{~g}$ of vigorously growing spawn of $P$. pulmonarius. The soil was contaminated with spent diesel oil to achieve $5 \%, 10 \%$ and $15 \%$ (w/v). The results showed a significant increase (at $p \leq 0.05)$ in the nutrient contents of the soil samples at all levels of contamination compared to the uncontaminated but there was no significant difference in the $\mathrm{pH}$ after two months of incubation with $P$. pulmonarius. The organic carbon increased from 2.176 to 6.960 at $0 \%$ and from 7.126 to 8.010 at $15 \%$ level of contaminations. Organic matter increased from 3.765 to 12.03 at $0 \%$ level of contamination and from 12.32 to 13.84 at $15 \%$. Phosphorus increased from 15.807 to 18.940 at $0 \%$ and 16.017 to 20.627 at $5 \%$ level of contaminations while Potassium increased from 0.660 to 0.783 at $0 \%$ and 0.540 to 0.837 at $10 \%$ level of contamination. The Total Petroleum Hydrocarbon (TPH) degradation (\% loss) was $84.41 \%$ at $5 \%, 64.87 \%$ at $10 \%$ and $44.27 \%$ at $15 \%$ level of contamination. . A significant $(p \leq 0.05)$ reduction in concentration of the heavy metals $\mathrm{Cu}$ and $\mathrm{Zn}$ after two months of incubation with $P$. pulmonarius suggested bioaccumulation. The Copper content reduced from 0.033 to $0.014 \mathrm{mg} / \mathrm{kg}$ at $0 \%$ oil contamination and from 0.027 to $0.021 \mathrm{mg} / \mathrm{kg}$ at $15 \%$ oil contamination while Zinc reduced from 0.076 to $0.059 \mathrm{mg} / \mathrm{kg}$ at $0 \%$ oil, and from 0.057 to $0.056 \mathrm{mg} / \mathrm{kg}$ at $15 \%$ oil contamination. There was an improvement in the growth of Corchorus olitorius in the remediated soil at all levels of contamination compared to the control. Plant growth in the remediated soil was $11.18 \mathrm{~cm}$ high after the sixth week while the control plant was $4.23 \mathrm{~cm}$ at $5 \%$ level contamination.

Conclusion and application: The fungus P.pulmonarius has been found from this study to be a potential white rot fungus that can bioremediate soil contaminated with diesel oil and that the remediated soil was able to support the growth of the test plant at all levels of contamination. The biotechnology is a cost effective energy input that can also fetch the farmer some income.
\end{abstract}

Key words: Bioremediation, Spent diesel oil, Degradation, P. pulmonarius, Soil nutrient content 


\section{INTRODUCTION}

Contamination of soil by oil spills is a wide spread environmental problem that often requires cleaning up of the contaminated sites (Bundy et al., 2002). This is because petroleum hydrocarbons in soils adversely affect the germination and growth of plants (Samina et al., 2001) by creating conditions which make essential nutrients like nitrogen and oxygen unavailable. According to Adam and Duncan (2002) this effect could be because the oil acts as a physical barrier preventing or reducing access of the seeds to water and oxygen. The economic growth that Nigeria has enjoyed as a result of oil revenue has had drawbacks through exposure of the population in oil producing areas to environmental contamination (Anoliefo and Vwioko 1995). The possibility of growing plants on soils contaminated by fuel or oil spills is one of the goals of bioremediation. Bossert and Bartha (1984) reported that (that petroleum hydrocarbon degradation is crucial to the rehabilitation of contaminated soil for plant growth. Soil remediation is defined by Allen (1988) as the return of soil to a condition of ecological stability together with the establishment of plant communities it supports or supported prior to disturbance. Among hydrocarbon pollutants, diesel oil is a complex mixture of alkanes and aromatic compounds that are frequently reported as soil contaminants leaking from storage tanks and pipelines or released in accidental spills (Gallego et al., 2001). Contamination of soil results in damage to crop growth; depending on the degree of contamination, the soil may remain unsuitable for plant growth for months or several years. The effect of contamination of soil with petroleum products on plants ranges from chlorosis, bleaching, spotting of leaves, necrosis, malformations to epidermal cells and mesophyll layers, yield reduction and impaired fecundity (Quinone-Aquilar et al., 2003). Achuba (2006) reported that toxic hydrocarbon molecules could inhibit the activities of amylase and starch

\section{MATERIALS AND METHODS}

The remediation experiment was conducted inside the Plant Physiology Laboratory at the University of Ibadan phosphorylase and thereby affect the assimilation of starch. Henner et al., (1999) reported that petroleum hydrocarbons consisting of small molecules and those that are water soluble are more phytotoxic to seed germination. Diesel fuel is not a systemic killer; it kills plants cells on contact.

Spent fuel was described by Wang et al., (2000) as a mixture of different chemicals including lubricative additives and heavy metals that come from engine parts as they wear away. Spent fuel is a toxic environmental contaminant not usually or naturally found in the environment (Dominguez-Rosado and Pitchtel, 2004). Due to the different composition of diesel fuel, it affects the environment in different forms. Thus, the organic carbon and mineral component in soil are affected at different rates. The implication of this is that the growth and development of organisms depending on such soils are affected at different rates (Wyszkowiski and Ziolkowski, 2008). Corchorus olitorius belongs to the family Tilicaceae. It is a semi woody herb of about $90 \mathrm{~cm}$ height and is commonly found in grassy savanna and widespread in the tropics and Australia. It is an important source of jute in India, but its utility in West Africa is rather as a vegetable, than for fiber production. It occurs as spontaneous weed during cultivation where it is left to mature for harvesting after the main crop, or it may be expressly cultivated. The leaf is rich in protein and has a high mineral content (Burkill, 2000). The white rot fungi $P$. pulmonarius is a wood decaying basidiomycetes which is capable of degrading not only lignin but also variable recalcitrant environmental pollutants due to its ability to secrete lignolytic enzymes such as lignin peroxidase, manganese peroxidase and laccases which aid in the degradation process (Ogbo et al., 2006). The study is aimed at investigating the potential of $P$. pulmonarius in the bioremediation of the spent diesel oil contaminated soil at different levels of contamination.

and the germination experiment was conducted in a greenhouse at the Department of Botany, University of 
Ibadan, Nigeria. Total class A pan evaporation of the greenhouse was about $1550-1660 \mathrm{~mm}$, the mean annual internal temperature ranged from $20-30^{\circ} \mathrm{C}$ (minimum) to $24-34^{\circ} \mathrm{C}$ (maximum). The relative humidity was lowest at $71 \%$ and highest at $88 \%$. The photosynthetic active radiation was generally high with a daily average of $780 \mu \mathrm{mol} \mathrm{m}^{-2} \mathrm{~s}^{-1}$. The top soil was obtained from the nursery area and sieved using a $2 \mathrm{~mm}$ mesh to remove gravel and debris. Pure culture of Pleurotus pulmonarius used was obtained from the Plant Physiology lab of the Department of Botany. Fungal cultivation and incubation was done according to the modified method of Adenipekun and Fasidi (2005). Four hundred grams of soil was weighed into sterile bottles. The soil was contaminated with spent diesel oil to achieve 5,10 , and $15 \%(\mathrm{v} / \mathrm{w})$, respectively, according to the method of Adenipekun and Kassim (2006). The oil was obtained from a diesel generator. Forty grams of moistened clean rice straw were laid on the contaminated soil in each bottle separated with wire gauze and covered with aluminum foil. The bottles were then autoclaved at $15 \mathrm{lbi}^{-1}$ pressure, and $121^{\circ} \mathrm{C}$ for twenty minutes. After cooling, each bottle was inoculated with $10 \mathrm{~g}$ of vigorously growing spawn of $P$.pulmonarius. The bottles were then incubated at room temperature for two months. At the end of the incubation period, the soil layer was separated from the mycelial - ramified substrate. The soil was dried and soil samples were analyzed for physio- chemical parameters and Total Petroleum Hydrocarbon (TPH). The seeds of $C$. olitorius were supplied by the Seed Technology Division of National Horticultural Research Institute (NIHORT), Ibadan. Twenty four nursery bags were filled with $380 \mathrm{~g}$ of soil that was remediated and the unremediated control and arranged on a platform in the greenhouse. The $0 \%$ was without spent diesel oil for both remediated and control treatments Ten seeds of $C$. olitorius were broadcast on the soil and a layer of dry fine sand was used to cover the seeds. The experiment was set in triplicates and watered every day.

\section{RESULTS AND DISCUSSION}

After two months of incubation, the organic carbon (OC $\%$ ) content increased from 2.20 to $6.96 \%$ in the control $(0 \%)$ (Table 1). For $5 \%$ level of contamination OC\% increased from 3.04 to $6.04 \%$ after 2 months; from 6.17 to $8.12 \%$ for $10 \%$ oil and $7.12 \%$ to $8.01 \%$ at $15 \%$ oil. The organic matter, phosphorus and potassium increased from 3.76 to $12.03 \%, 15.81$ to $18.9 \mathrm{mg} / \mathrm{kg}$ and 0.66 to
Measurements and data recorded: The soil $\mathrm{pH}$ was determined using the Bates (1954) method by weighing $20 \mathrm{~g}$ of soil and adding $20 \mathrm{ml}$ of distilled water. The mixture was allowed to stand for about 30 minutes. The glass electrode $\mathrm{pH}$ meter was used to take the readings. Organic Carbon, Organic Matter, Percentage Nitrogen, Phosphorus and Potassium were determined using the Official Methods of Association of Analytical Chemists (A.O.A.C, 2003). Heavy metals content of the soil samples was determined by the double acids methods of (A.O.A.C, 2003). Intergovernmental Oceanographic Commission (IOC) method as described by Oniawa and Essein (1999) was used to determine the total petroleum hydrocarbon content. Growth parameters were taken two weeks after planting when the number of seedlings in each bag had been trimmed down to two (Odjegba and Sadiq, 2002). Plant height was measured with a meter rule from soil level to the tip of the terminal bud. This was done for the two seedlings in each bag and the mean value was calculated. The stem girth was taken $2 \mathrm{~cm}$ above the soil level with digital vernier caliper. The number of leaves was counted, leaf area determined by the method of Hoyt and Bradfield (1962) by multiplying the leaf length, leaf breadth and 0.75 (which serve as correction factor for the leaf area). All measurements were carried out weekly until the end of the sixth week when the plants were harvested and the total root length was determined using a meter rule as the distance from the soil level to the tip of the tap root. The fresh weight was taken immediately and dry weight of the plant determined for both the remediated and control at all levels of contamination using a Metller weighing balance after oven drying at $80^{\circ} \mathrm{C}$ to a constant weight using a Gallenkamp Oven (Model 1H-150). Moisture content was determined as the difference between the fresh weight and dry weight of plant. Statistical analysis of the data was by analysis of variance (ANOVA) and the different means of treatment compared using Duncan's Multiple Range Test ( $p \leq 0.05)$.

$0.78 \mathrm{cmol} / \mathrm{kg}$, respectively, after two months of incubation in the control $(0 \%)$. A similar trend was observed for the other levels of contamination for organic matter and phosphorus. Adenipekun and Omoruyi (2008) reported an increase in organic carbon and organic matter of crude oil contaminated soil when treated with Pleurotus ostreatus after two months of incubation compared to the soil. 
Table 1: Nutrient contents of diesel oil contaminated soil incubated with Pleurotus pulmonarius

\begin{tabular}{l|c|c|c|c|c|c|c}
\hline $\begin{array}{l}\text { Contamination } \\
\text { level }\end{array}$ & $\begin{array}{c}\text { Incubation } \\
\text { period }\end{array}$ & $\begin{array}{c}\text { Organic } \\
\text { Carbon (\%) }\end{array}$ & $\begin{array}{c}\text { Organic } \\
\text { matter (\%) }\end{array}$ & $\begin{array}{c}\text { Nitrogen } \\
(\mathbf{m g} / \mathrm{kg})\end{array}$ & $\begin{array}{c}\text { Phosphorus } \\
(\mathrm{mg} / \mathrm{kg})\end{array}$ & $\begin{array}{c}\text { Potassium } \\
(\mathrm{cmol} / \mathrm{kg})\end{array}$ & $\mathbf{p H}$ \\
\hline Control(0\% & 0 month & $2.176^{\mathrm{c}}$ & $3.763^{\mathrm{c}}$ & $1.077^{\mathrm{a}}$ & $15.807^{\mathrm{a}}$ & $0.660^{\mathrm{a}}$ & $6.384^{\mathrm{a}}$ \\
& 2 month & $6.960^{\mathrm{a}}$ & $12.03^{\mathrm{a}}$ & $0.620^{\mathrm{b}}$ & $18.940^{\mathrm{a}}$ & $0.783^{\mathrm{a}}$ & $6.571^{\mathrm{a}}$ \\
\hline $5 \%$ & 0 month & $3.043^{\mathrm{c}}$ & $5.260^{\mathrm{c}}$ & $1.537^{\mathrm{a}}$ & $16.017^{\mathrm{b}}$ & $0.567^{\mathrm{a}}$ & $6.362^{\mathrm{a}}$ \\
& 2 month & $6.746^{\mathrm{a}}$ & $11.66^{\mathrm{a}}$ & $1.117^{\mathrm{a}}$ & $20.627^{\mathrm{a}}$ & $0.517^{\mathrm{a}}$ & $6.607^{\mathrm{a}}$ \\
\hline $10 \%$ & 0 month & $6.170^{\mathrm{c}}$ & $10.666^{\mathrm{c}}$ & $3.087^{\mathrm{a}}$ & $17.610^{\mathrm{a}}$ & $0.540^{\mathrm{b}}$ & $6.5370^{\mathrm{a}}$ \\
& 2 month & $8.120^{\mathrm{a}}$ & $14.033^{\mathrm{a}}$ & $1.997^{\mathrm{b}}$ & $15.290^{\mathrm{ab}}$ & $0.837^{\mathrm{a}}$ & $6.6130^{\mathrm{a}}$ \\
\hline $15 \%$ & 0 month & $7.126^{\mathrm{a}}$ & $12.32^{\mathrm{a}}$ & $3.527^{\mathrm{a}}$ & $19.950^{\mathrm{a}}$ & $0.593^{\mathrm{a}}$ & $6.511^{\mathrm{a}}$ \\
& 2 month & $8.010^{\mathrm{a}}$ & $13.84^{\mathrm{a}}$ & $1.850^{\mathrm{b}}$ & $19.360^{\mathrm{a}}$ & $0.860^{\mathrm{a}}$ & $6.651^{\mathrm{a}}$ \\
\hline
\end{tabular}

Each value is a mean of three replicates. Values in the same column followed by the same letters are not significantly different according to Duncan multiple range test at $(P \leq 0.05)$.

Table 2: Total Petroleum Hydrocarbon (TPH) in soil polluted with diesel oil after two months of incubation.

\begin{tabular}{l|l|l|l}
\hline Treatments & \multicolumn{2}{|c|}{ Incubation period } & \multirow{2}{*}{ TPH (\% lost) } \\
\cline { 1 - 3 } Concentration of spent diesel oil (\%) & \multicolumn{2}{|c|}{ TPH (mg $/ \mathbf{k g})$} & \\
\cline { 2 - 3 } & $12130 \pm 0.02$ & $1890 \pm 0.03$ & 84.41 \\
\hline 5 & $22940 \pm 0.05$ & $8750 \pm 0.05$ & 61.875 \\
\hline 10 & $25900 \pm 0.15$ & $14432 \pm 0.01$ & 44.27 \\
\hline 15 & & &
\end{tabular}

Each Value is a mean of three replicates with the standard error of the mean

It was observed that the efficacy of the fungus in TPH degradation was adversely affected with increase in concentration of diesel oil in the soil. It was noticed that the fungus first biodegraded the diesel before mineralizing it. For the fungus to perform the reduction it was found that they have to biodegrade and then mineralization of this oil will take place. The highest level of degradation was at $5 \%$ oil contamination and the least at $15 \%$ contamination Isikhuemhen et al., (2003) recorded a $96.46 \%$ in the total petroleum hydrocarbon removal from engine oil contaminated soil at $1 \%$ level of contamination incubated with Lentinus squarrosulus another white rot fungus. Canet et al (2001) reported that $P$. ostreatus was able to remove up to $90 \%$ of the total poly aromatic hydrocarbons present in contaminated soils. Adenipekun et al (2011) also observed that $P$. tuber-regium another white rot fungus was able to degrade the total petroleum hydrocarbon in soil contaminated with cutting fluids.

Table 3: Heavy metals content $(\mathrm{mg} / \mathrm{kg})$ of soil contaminated with diesel oil incubated with Pleurotus pulmonarius.

\begin{tabular}{l|c|c|c|c|c}
\hline Treatment & Incubation period (month) & Manganese (Mn) & Copper ( Cu) & Zinc (Zn) & Lead (Pb) \\
\hline Control (0\%) & 0 & $0.039^{\mathrm{a}}$ & $0.035^{\mathrm{a}}$ & $0.076^{\mathrm{a}}$ & $0.020^{\mathrm{b}}$ \\
& 2 & $0.051^{\mathrm{a}}$ & $0.014^{\mathrm{b}}$ & $0.059^{\mathrm{b}}$ & $0.029^{\mathrm{a}}$ \\
\hline $5 \%$ & 0 & $0.036^{\mathrm{a}}$ & $0.019^{\mathrm{a}}$ & $0.060^{\mathrm{a}}$ & $0.037^{\mathrm{ab}}$ \\
& 2 & $0.049^{\mathrm{a}}$ & $0.022^{\mathrm{a}}$ & $0.057^{\mathrm{a}}$ & $0.052^{\mathrm{a}}$ \\
\hline $10 \%$ & 0 & $0.038^{\mathrm{a}}$ & $0.021^{\mathrm{c}}$ & $0.064^{\mathrm{a}}$ & $0.046^{\mathrm{a}}$ \\
& 2 & $0.040^{\mathrm{a}}$ & $0.023^{\mathrm{a}}$ & $0.059^{\mathrm{b}}$ & $0.069^{\mathrm{ab}}$ \\
\hline $15 \%$ & 0 & $0.036^{\mathrm{a}}$ & $0.027^{\mathrm{a}}$ & $0.057^{\mathrm{a}}$ & $0.059^{\mathrm{a}}$ \\
& 2 & $0.054^{\mathrm{a}}$ & $0.021^{\mathrm{a}}$ & $0.056^{\mathrm{a}}$ & $0.075^{\mathrm{a}}$ \\
\hline
\end{tabular}

Each value is a mean of three replicates. Values in the same column followed by the same letters are not significantly different according to Duncan multiple range test at $(\mathrm{P} \leq 0.05)$. 
The results of heavy metals content in soil with spent diesel after two months of incubation (table 3 ) shows that $P$. pulmonarius accumulated copper and zinc into its straw/fungal biomass with a reduction in the copper content in the control from 0.0346 to $0.01433 \mathrm{mg} / \mathrm{kg}$ and zinc reduction from 0.0756 to $0.0596 \mathrm{mg} / \mathrm{kg}$.

In the other levels of contaminations, zinc content reduced from 0.06067 to $0.0573 \mathrm{mg} / \mathrm{kg}$ in $5 \%$ oil, 0.06433 to $0.0590 \mathrm{mg} / \mathrm{kg}$ and 0.0576 to $0.0560 \mathrm{mg} / \mathrm{kg}$ in $10 \%$ and $15 \%$ respectively. Copper content reduced from $0.0346 \mathrm{mg} / \mathrm{kg}$ in the control $(0 \%)$ to 0.014 and from $0.027 \mathrm{mg} / \mathrm{kg}$ to $0.021 \mathrm{mg} / \mathrm{kg}$ at $15 \%$ level of oil contamination. Adenipekun and Isikhuemhen (2008) also observed an increase in the heavy metals content of another white rot fungus Lentinus subnudus showing an accumulation of the heavy metals. The reduction in the heavy metals implied a bioaccumulation of these metals by $P$. pulmonarius and reduction in the toxicity in the soil. The results showed a marked difference in growth of the plants in remediated soil and the control at all level of contamination of soil with spent diesel oil. The remediated plant was taller, had larger leaves and had bigger stems compared to those growing in non-remediated soil(Table 4). The result also showed that the number of leaves of plants in the soil that was remediated with $P$. pulmonarius (treatments) was higher than that of the soil that was not remediated (control) at all levels of contamination. At the end of the sixth week the average number of leaves of plants in the control regime (0\%) was 13.5 while that of plants (that was remediated with the fungus was 28.66. The same trend was observed in the other levels of contamination having the number of leaves increased from 4.33 in the soil that was not remediated to 10.66 in the soil that was remediated at $5 \%$ level of contamination at the end of sixth week. It would be recalled that fungus brings about remediation of the soil prior to planting of seed of $C$. olitorius and in the process increased the nutrient content of the soil.

Table 4: Leaf number of $C$. olitorius grown on soil remediated using Pleurotus pulmonarius after contamination with spent diesel oil.

\begin{tabular}{l|l|l|l|l|l|l}
\hline Treatment & $\begin{array}{l}\text { Incubation } \\
\text { period }\end{array}$ & Week 1 & Week 2 & Week 3 & Week 4 & Week 5 \\
\hline $0 \%$ & Non-remediated & $4.166^{\mathrm{b}}$ & $6.500^{\mathrm{b}}$ & $9.164^{\mathrm{b}}$ & $10.00^{\mathrm{b}}$ & $13.500^{\mathrm{b}}$ \\
& Remediated & $5.335^{\mathrm{a}}$ & $8.167^{\mathrm{a}}$ & $14.500^{\mathrm{a}}$ & $20.500^{\mathrm{a}}$ & $28.666^{\mathrm{a}}$ \\
\hline $5 \%$ & Non-remediated & $2.166 \mathrm{~b}$ & $3.000^{\mathrm{b}}$ & $3.000^{\mathrm{b}}$ & $3.500^{\mathrm{b}}$ & $4.3333^{\mathrm{b}}$ \\
& Remediated & $4.000^{\mathrm{a}}$ & $4.833^{\mathrm{a}}$ & $7.666^{\mathrm{a}}$ & $9.166^{\mathrm{a}}$ & $10.666^{\mathrm{a}}$ \\
\hline $10 \%$ & Non-remediated & $0.000^{\mathrm{b}}$ & $2.000^{\mathrm{b}}$ & $2.000^{\mathrm{b}}$ & $2.000^{\mathrm{b}}$ & $2.333^{\mathrm{b}}$ \\
& Remediated & $2.000^{\mathrm{a}}$ & $4.666^{\mathrm{a}}$ & $5.666^{\mathrm{a}}$ & $7.333^{\mathrm{a}}$ & $8.000^{\mathrm{a}}$ \\
\hline $15 \%$ & Non-remediated & $0.000^{\mathrm{b}}$ & $2.000^{\mathrm{b}}$ & $2.000^{\mathrm{b}}$ & $2.000^{\mathrm{b}}$ & $2.000^{\mathrm{b}}$ \\
& Remediated & $2.000^{\mathrm{a}}$ & $3.166^{\mathrm{a}}$ & $3.666^{\mathrm{a}}$ & $4.166^{\mathrm{a}}$ & $4.500^{\mathrm{a}}$ \\
\hline
\end{tabular}

Each value is a mean of six replicates. Values in the same column followed by the same letters are not significantly different according to Duncan Multiple Range Test at $(P \leq 0.05)$.

Table 5: Shoots height of $C$. olitorius grown on soil remediated using Pleurotus pulmonarius after contamination with spent diesel oil.

\begin{tabular}{l|l|l|l|l|l|l}
\hline \multirow{2}{*}{ Oil level (\%) } & Treatment & \multicolumn{5}{|c}{ Incubation period } \\
\cline { 3 - 6 } & & Week 1 & Week 2 & Week 3 & Week 4 & Week 5 \\
\hline 0 & Non-remediated & $5.216^{\mathrm{b}}$ & $7.717^{\mathrm{b}}$ & $12.33^{\mathrm{a}}$ & $12.733^{\mathrm{b}}$ & $21.033^{\mathrm{b}}$ \\
& Remediated & $5.983^{\mathrm{a}}$ & $11.383^{\mathrm{a}}$ & $17.500^{\mathrm{a}}$ & $21.700^{\mathrm{a}}$ & $33.133^{\mathrm{a}}$ \\
\hline 5 & Non-remediated & $2.433^{\mathrm{b}}$ & $3.116^{\mathrm{b}}$ & $3.583^{\mathrm{b}}$ & $3.600^{\mathrm{b}}$ & $4.233^{\mathrm{b}}$ \\
& Remediated & $4.116^{\mathrm{a}}$ & $5.716^{\mathrm{a}}$ & $7.700^{\mathrm{a}}$ & $9.483^{\mathrm{a}}$ & $11.183^{\mathrm{a}}$ \\
\hline 10 & Non-remediated & $0.000^{\mathrm{b}}$ & $0.000^{\mathrm{b}}$ & $1.116^{\mathrm{b}}$ & $1.400^{\mathrm{b}}$ & $1.683^{\mathrm{b}}$ \\
& Remediated & $4.833^{\mathrm{a}}$ & $5.650^{\mathrm{a}}$ & $5.750^{\mathrm{a}}$ & $5.783^{\mathrm{a}}$ & $7.900^{\mathrm{a}}$ \\
\hline 15 & Non-remediated & $0.000^{\mathrm{b}}$ & $0.000^{\mathrm{b}}$ & $0.783^{\mathrm{b}}$ & $1.150^{\mathrm{b}}$ & $1.300^{\mathrm{b}}$ \\
& Remediated & $2.083^{\mathrm{a}}$ & $2.315^{\mathrm{a}}$ & $2.533^{\mathrm{a}}$ & $3.233^{\mathrm{a}}$ & $4.083^{\mathrm{a}}$
\end{tabular}

Each value is a mean of six replicates. Values in the same column followed by the same letters are not significantly different according to Duncan Multiple Range Test at $(\mathrm{P} \leq 0.05)$ 
Results (Table 4) also showed that as the level of contamination increased in the soil the number of leaves reduced from 13.50 at $0 \%$ oil to 4.33 at $5 \%, 2.33$ at $10 \%$ and 2.00 at $15 \%$ oil contamination at the end of the sixth week. Smith et al. (1989) reported that insufficient aeration resulting from oil contamination in soil caused stem rot, which consequently reduced plant growth The results (table 5) showed a marked difference between the control and treatment plant at all levels of contamination. The plants in the soil that was remediated were taller compared to those of the soil that was not remediated at all levels of contamination. At the end of the sixth week the height of the control plant $(0 \%)$ that was not remediated was $21.033 \mathrm{~cm}$ while that of the plants in soil that was remediated was $33.133 \mathrm{~cm}$. Olusola and Anslemm (2010) reported a similar finding using $P$. pulmonarius for the bioremediation of soil contaminated with crude oil and Amaranthus hybridus as test plants.. The results showed that the leaf area in the control $(0 \%)$ plant at the end of the third week was $8.176 \mathrm{~cm}^{2}$ while that of the plants in remediated soil was $10.910 \mathrm{~cm}^{2}(\mathrm{Fig} 1)$.

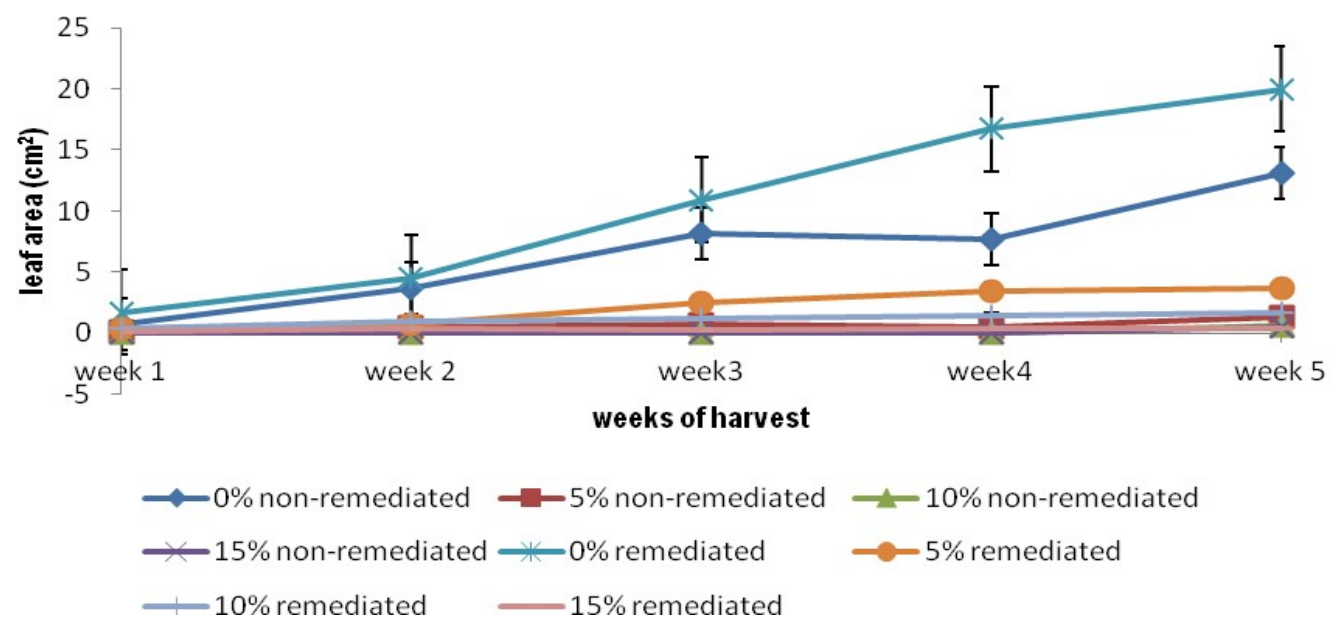

Fig. 1: Leaf area of $C$. olitorius grown on soil remediated using Pleurotus pulmonarius after contamination with spent diesel oil

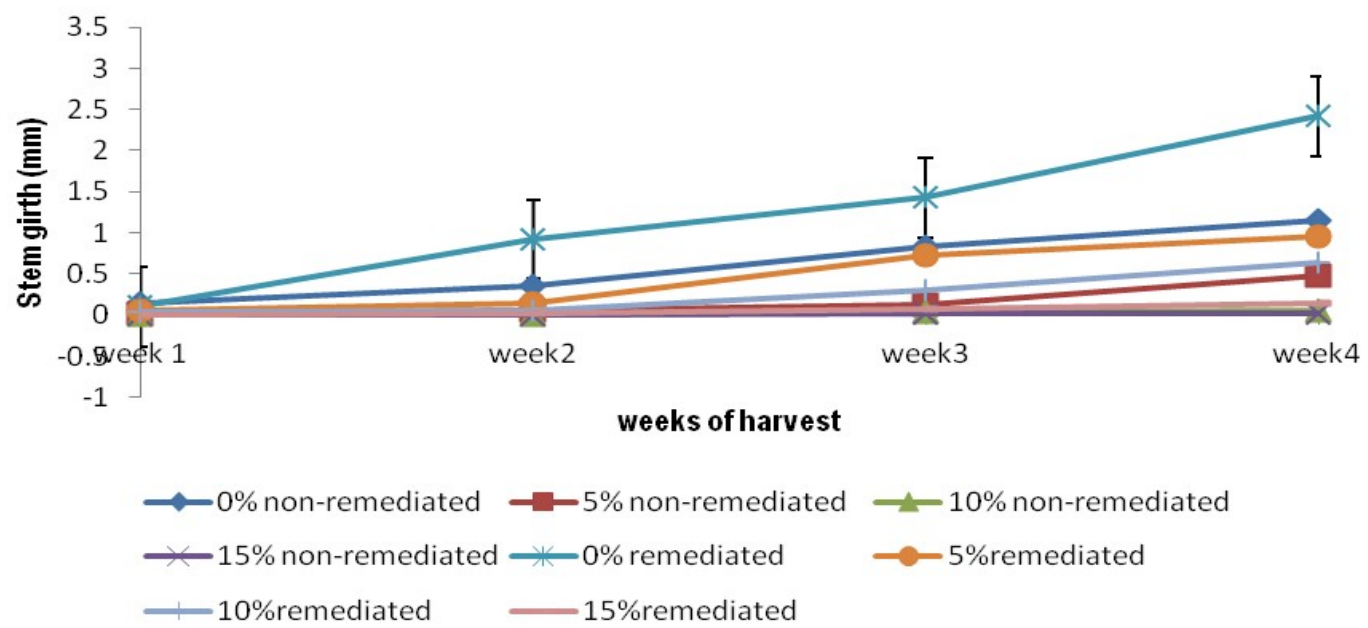

Fig 2: Stem girth of $C$. olitorius grown on soil remediated using Pleurotus pulmonarius after contamination with spent diesel oil.

At the end of the sixth week the leaf area in the non remediated soil was $13.09 \mathrm{~cm}^{2}$ at $0 \%$ level of contamination, $1.331 \mathrm{~cm}^{2}$ at $5 \%, 0.660 \mathrm{~cm}^{2}$ at $10 \%$ and $0.451 \mathrm{~cm}^{2}$ at $15 \%$ level of contamination, respectively. The same trend was observed for the leaf area of plant in the soil that was incubated with the fungus, at the end of the sixth week. Similarly Adenipekun et al. (2009) showed that spent engine oil has potential adverse effects on 
Okra plants, as observed that there was reduction in shoot height, leaf numbers and leaf area of the plants that was contaminated with oil compared to the control. The stem girth of the plant of the $0 \%$ ( not inoculated with the fungus) was $0.96 \mathrm{~mm}$ at the end of the sixth week and $2.678 \mathrm{~mm}$ in the remediated soil at $0 \%$ level of contamination, 0.128 and $1.05 \mathrm{~mm}$ in the $5 \%$.

Table 6: Root length, Fresh weight, Dry weight and Moisture content of $C$. olitorius grown on soil remediated using Pleurotus pulmonarius after contamination with spent diesel oil

\begin{tabular}{l|l|l|l|l|l|l}
\hline $\begin{array}{l}\text { Contamination } \\
\text { levels } \\
\%\end{array}$ & Treatments & $\begin{array}{c}\text { Incubation } \\
\text { period } \\
\text { (month) }\end{array}$ & $\begin{array}{l}\text { Root length } \\
(\mathbf{c m})\end{array}$ & $\begin{array}{c}\text { Fresh weight } \\
\mathbf{( g )}\end{array}$ & $\begin{array}{c}\text { Dry weight } \\
\mathbf{( g )}\end{array}$ & $\begin{array}{c}\text { Moisture } \\
\text { content } \\
(\%)\end{array}$ \\
\hline Control(0) & Non remediated & 0 & $5.883^{\mathrm{b}}$ & $3.400^{\mathrm{a}}$ & $1.165^{\mathrm{a}}$ & $2.235^{\mathrm{b}}$ \\
& Remediated & 2 & $10.067^{\mathrm{a}}$ & $7.633^{\mathrm{a}}$ & $1.381^{\mathrm{a}}$ & $6.252^{\mathrm{a}}$ \\
\hline 5 & Non remediated & 0 & $2.667^{\mathrm{b}}$ & $0.532^{\mathrm{b}}$ & $0.005^{\mathrm{b}}$ & $0.527^{\mathrm{b}}$ \\
& Remediated & 2 & $5.333^{\mathrm{a}}$ & $1.110^{\mathrm{a}}$ & $0.338^{\mathrm{a}}$ & $0.772^{\mathrm{a}}$ \\
\hline 10 & Non remediated & 0 & $1.866^{\mathrm{b}}$ & $0.030^{\mathrm{b}}$ & $0.002^{\mathrm{b}}$ & $0.028^{\mathrm{b}}$ \\
& Remediated & 2 & $2.983^{\mathrm{a}}$ & $0.161^{\mathrm{a}}$ & $0.120^{\mathrm{a}}$ & $0.041^{\mathrm{a}}$ \\
\hline 15 & Non remediated & 0 & $2.050^{\mathrm{a}}$ & $0.017^{\mathrm{b}}$ & $0.001^{\mathrm{b}}$ & $0.016^{\mathrm{b}}$ \\
& Remediated & 2 & $2.650^{\mathrm{a}}$ & $0.137^{\mathrm{a}}$ & $0.082^{\mathrm{a}}$ & $0.055^{\mathrm{a}}$ \\
\hline
\end{tabular}

Each value is a mean of six replicates. Values in the same column followed by the same letters are not significantly different according to Duncan Multiple Range Test at $(P<0.05)$

Adenipekun and Kassim (2006) opined that the reduction in stem girth with increase in concentration of spent oil in soil could be due to the reduction in nutrient uptake by the plants. The plants in remediated soil performed better than the control plants because the fungus was able to bioaccumulate heavy metals from the non- contaminated soil and therefore reduces its toxicity. The results (table 6) showed that the root length of the plant in the nonremediated soil after the sixth week was $5.883 \mathrm{~cm}$ while that of the remediated soil was $10.07 \mathrm{~cm}$. At $5 \%$ oil contamination the root length was $2.67 \mathrm{~cm}, 1.87 \mathrm{~cm}$ in $10 \%$ and $2.05 \mathrm{~cm}$ in $15 \%$ in the non remediated soil while those of the remediated soil was $5.33 \mathrm{~cm}$ at $5 \%, 2.98 \mathrm{~cm}$ at $10 \%$ and $2.605 \mathrm{~cm}$ at $15 \%$ level of contamination. The fresh weight of plants was higher in remediated soil than those in non remediated soils for all the levels of contamination (table 6).In non- remediated soil, at 5\% level of contamination the plant fresh weight was $0.53 \mathrm{~g}$ in $0.03 \mathrm{~g}$ in $10 \%$ and $0.02 \mathrm{~cm}$ in $15 \%$ while that of remediated plants was $1.10 \mathrm{~g}$ in $5 \%, 0.16 \mathrm{~g}$ in $10 \%$ and $0.13 \mathrm{~g}$ in $15 \%$

\section{CONCLUSION AND RECOMMENDATIONS}

The results of this study show that the spillage of diesel oil can have adverse effects on plants growth and yield. Importantly, the study demonstrates on a small scale that the mycelium of $P$. pulmonarius can be useful in the bioremediation of soils contaminated with diesel oil. To level of contamination. The dry weight was $1.16 \mathrm{~g}$ at the end sixth week for the $0 \%, 0.005 \mathrm{~g}$ for $5 \%, 0.002 \mathrm{~g}$ for $10 \%$ and $0.001 \mathrm{~g}$ for $15 \%$ respectively for the soil that was not remediated while that of the plants in remediated soil was $1.38 \mathrm{~g}$ for $0 \%, 0.34 \mathrm{~g}$ for $5 \%, 0.12 \mathrm{~g}$ for $10 \%$ and $0.08 \mathrm{~g}$ for $15 \%$ oil level. The results showed a lower level of moisture content in plants grown in soil that was not remediated. The higher the percentage of contamination the lower the moisture content of $C$. olitorius. Adenipekun et al (2009) reported a similar finding on C. olitorius using spent engine oil. The presence of spent diesel oil in the soil that was not remediated might have reduced the amount of water available for plant absorption. The results suggested that the soil-plant -water relation might have been affected due to exclusion of air and water from the pores and air spaces. This creates an oxygen tension in such oil polluted soil leading to the death of root hairs. The consequence is reduced water absorption and distorted root growth and development as recorded in this study.

exploit the findings of this study we recommend that farmers can pre -cultivate their polluted farmlands with P.pulmonarius which can greatly ameliorate effects of pollution. 


\section{REFERENCES}

Achuba FI, 2006. The effect of sub lethal concentrations of crude oil on the growth and metabolism of Cowpea (Vigna unguiculata) seedlings. Environmentalist, 26: 17-20.

Adam G. and Duncan HJ, 2002. Influence of Diesel Fuel on Seed Germination. Environ. Pollut., 120:363-370.

Adenipekun CO, and Fasidi IO, 2005. Bioremediation of oilpolluted soil by Lentinus subnudus, a Nigerian whiterot fungus. Afr. J. Biotech. 4(8): 796-798.

Adenipekun CO and Isikhuemhen O.S. (2008). Bioremediation of engine oil polluted soil by the tropical white-rot fungus Lentinus squarrosulus Mont.Singer. Pak.J.Biol.Sci 11(2):1634-1637.

Adenipekun CO and Kassim LQ. 2006. Effects of spent engine oil on some growth parameters and moisture content of Celosia argentea L. Nigerian J Bot 19(2):318-324.

Adenipekun CO and Omoruyi O.M. (2008). Bioremediation of contaminated soils by Pleurotus ostreatus.Nig.J.Bot 29(2):274-279.

Adenipekun CO, Oyetunji OJ Kassim LS, 2008. Effect of engine oil on the growth parameters and chlorophyll content of Corchorus olitorius Linn, Environmentalist 28: 446-450.

Adenipekun CO, Oyetunji OJ and Kassim LS (2009).Screening of Abelmoschus esculentus L.Moench for tolerance to spent engine oil. Journ.Appl.Biosciences 20: 1131 . 1137.

Adenipekun CO, Ejoh OE, Ogunjobi, AA, 2011. Bioremediation of cutting fluids contaminated soil by Pleurotus tuberregium Singer. Enviromentalist 32(1): 11-18.

Allen EB, 1988. The reconstruction of disturbed arid lands: Anceological approach. In: Glenn, E. P., Waugh, W. J., Moore, D., Mckeon, C. and Nelson, S. G (Eds.). Revegetation of an abandoned uranium millsite on the Colorado Plateau, Arizona.

Anoliefo GS, and Vwioko DE, 1995. Effects of spent lubricant on the growth of Capsicum annum L. and Lycopersicum esculentum Miller. Environ Pollut 88(3):361-364.

AOAC 2003 .Association of Official Analytical Chemists;Methods of Analysis,Washington D.C.

Bates RA 1954 . Electrometric determination.John Wiley Sons Inc.New York.

Bossert I, and Bartha RA, 1984. The fate of petroleum in soil ecosystem. In: Petroleum Microbiology. Macmillan, New York. pp. 435-475.

Bundy J G, Paton GI, and Campbell CD, 2002. "Microbial communities in different soil types do not converge after diesel contamination." J. Appl. Microbiol., 92: 276-288.

Burkill HM, 2000. The useful plants of West Tropical Africa. Royal Botanical Gardens Kew. pp 960.

Canet R.,Birnstingl IG,Malcolm DG,Lopez-Real JM, and Beck AJ 2001.Biodegradation of polycyclic aromatic
hydrocarbons(PAHs) by native microflora nd combinations of white-rot fungi in a coal-tar contaminated soil. Bioresource Technol., 76:113117.

Dominguez-Rosado RE, and Pichtel J, 2004. Phytoremediation of soil contaminated with used motor oil. Enhanced microbial activities from laboratory and growth chamber studies. Environ. Eng. Sci., 2: 157- 168.

Gallego JR, Loredo J, Llamas JF, Vazquez F, Sanschez J , 2001. Bioremediation of diesel-contaminated soils: evaluation of potential in situ techniques by study of bacterial degradation. Biodegradation 12: 325-335.

Henner P, Schiavon M, Druelle V, Lichtfouse E, 1999. Phytotoxicity of ancient gaswork soils. Effect of polycyclic aromatic hydrocarbons (PAHs) on plant germination. Organic Geochemistry, 30, 963-969.

Hoyt $P$, and Bradfield $R$, 1962. Effects of varying leaf area by defoliation and density on the dry matter production of corn. Agro J. 54: 523-524.

Isikhuemhen, O.S. and Anoliefo G., Oghale,O. 2003. Bioremediation of crude-oil polluted soil by the whiterot fungus, Pleurotus tuber-regium (Fr,) Sing. Environ.Sci.Pollut.Res.10:108-112.

Odjegba V, and Sadiq AO, 2002. Effects of spent engine oil on the growth parameters, chlorophyll and protein levels of Amaranthus hybridus L. The Environmentalist, 22: 23-28.

Ogbo EM, 2006. Studies on growth of Pleurotus tuber-regium Fr. Singer in crude oil contaminated soils. Ph.D Thesis, Department of Botany, University of Benin city, Nigeria, 295pp

Olusola SA, and Anslem EE, 2010. Bioremediation of a Crude Oil Polluted Soil with Pleurotus pulmonarius and Glomus mosseae using Amaranthus hybridus as a Test Plant. J Bioremed Biodegrad 1:111. doi:10.4172/2155-6199.1000113.

Onianwa PC, and Essien, R. 1999. Petroleum hydrocarbon levels in sediments of stream and river within Ibadan city, Nigeria. Bull. Chem. Soc. Ethiopia, 13: 82-85.

Quinones-Aquilar EE, Ferra-Cerrato R, Gavi, RF, Fernandez L, and Rodriguez VR, 2003. Emergence and growth of maize in a crude oil polluted soil. Agrociencia 37: 585-594.

Samina BE, Glaser JA, Baveye PV, 2001. The utilization of bioremediation to reduce soil contamination: problems and solutions. Dordrecht: Kluwer Academic Publishers.

Wang J, Jia CR, Wong CK, and Wong PK , 2000. Characteristics of polycyclic aromatic hydrocarbon created in lubricating oils. Water, Air Pollut., 120: 381-396.

Wyszkowiski M, Ziolkowski AS, 2008. Effect of petrol and diesel oil on content of organic carbon and mineral 
components in soil. American-Eurasian $\mathrm{J}$.

Sustainable Agric., 2(1): 54-60. 